Western North American Naturalist 69(3), (C) 2009, pp. 299-308

\title{
CADDISFLY (TRICHOPTERA) ASSEMBLAGES ALONG MAJOR RIVER DRAINAGES IN ARIZONA
}

\author{
Dean W. Blinn ${ }^{1,3}$ and David E. Ruiter ${ }^{2}$
}

\begin{abstract}
Seventy-two caddisfly species in 36 genera and 15 families were collected along the Little Colorado, Verde, Gila, and Colorado rivers in Arizona. Brachycentrids, hydropsychids, limnephilids, and uenoids made up nearly $50 \%$ of the assemblage in forested sites above $2200 \mathrm{~m}$. Hydropsychids, hydroptilids, and leptocerids made up $75 \%$ of the assemblage in grassland watersheds between 2200 and $1000 \mathrm{~m}$, and $80 \%$ at sites below $1000 \mathrm{~m}$ in desert watersheds. Species richness averaged 16 at sites above $2200 \mathrm{~m}$ elevation, 7 between 2200 and $1000 \mathrm{~m}$, and 3 below $1000 \mathrm{~m}$. H' diversity was typically $>3$ at sites above $2200 \mathrm{~m}$ and $<2.5$ below $2200 \mathrm{~m}$. Each river had distinct faunas likely due to isolation of drainages across semiarid landscapes. Low Sørensen similarity values were measured for caddisfly assemblages in the highly regulated Colorado River and the other 3 rivers. Only 17 species were collected at 14 sites along $700 \mathrm{~km}$ of the Colorado River. Indicator caddisfly species are provided for altered and less disturbed drainages. We added 7 species not previously reported in Arizona for a total of 154 caddisfly species in the state. We provide a baseline of caddisfly indicators for monitoring changes in ecosystem health during the predicted long-term drought and population expansion in southwestern USA.
\end{abstract}

Key words: Trichoptera, Colorado River, Gila River, Little Colorado River, Verde River, elevation, semiarid landscapes, species richness, indicator species.

Arizona has a number of streams that flow from subalpine coniferous forests to arid deserts. These streams flow through 4 major river drainages including the Little Colorado (LCR), Verde, Gila, and Colorado rivers. Watersheds as well as physicochemical conditions and biota change dramatically in stream channels along elevation gradients (Blinn and Poff 2005). Yet few invertebrates have been cataloged along these drainages.

Previous reports on caddisfly distribution in Arizona have been largely restricted to localized areas, including Oak Creek in north central Arizona (May 1972, Parrott 1975, Scott 1982, Dehoney and Gaud 1983, Moulton et al. 1994, Blinn and Ruiter 2009) and the White Mountains in eastern Arizona (Houghton 2001). Spindler (1996) correlated caddisfly genera in the Little Colorado, Verde, and Gila rivers with ecoregions. Finally, Blinn and Ruiter (2006) compared 104 caddisfly species to channel conditions at 93 sites in 49 streams throughout Arizona, but species composition was not reported at each site.

Blinn and Ruiter (2006) reported low channel embeddedness $(\leq 5 \%)$ at sites on the LCR above $2200 \mathrm{~m}$ and high channel embeddedness $(\geq 70 \%)$ for rivers below $2200 \mathrm{~m}$ due to heavy agriculture and grazing on the watersheds (Table 1). Watersheds above $2200 \mathrm{~m}$ were typically forested, while those below $2200 \mathrm{~m}$ were mostly semiarid grassland and desert. Riparian vegetation changed from willow-alder in the upper sites to cottonwood-sycamore at moderate elevations to mesquite and the invasive saltcedar at lower elevations (Blinn and Poff 2005).

In this study, we collected caddisfly species at sites along the Little Colorado, Verde, Gila, and Colorado rivers in Arizona and compared species assemblages with elevation, watershed, and stream-channel conditions. The information in this report provides a baseline for monitoring changes in ecosystem health during the predicted long-term drought and population expansion in southwestern USA (Seager et al. 2007).

\section{STUdy Sites}

Thirty-three sites were grouped into 3 elevation ranges based on watershed. Watersheds $>2220 \mathrm{~m}$ were primarily forested; those

${ }^{1}$ Department of Biological Sciences, Northern Arizona University, Flagstaff, AZ 86011

26260 South Grant Street, Centennial, CO 80121.

${ }^{3}$ Present address: 3300 Spyglass Drive, Bellingham, WA 98226. E-mail: deandiacad@comcast.net 
TABLE 1. Stream site locations, percent channel embeddedness (\% EMBED), percent canopy cover, and elevation $(\mathrm{m})$ along the Little Colorado, Verde, Gila, and Colorado rivers, Arizona. Information was taken from Blinn and Ruiter (2006) except for Access Rd LCR, Winslow LCR, Cameron LCR, Gila River Grapevine, and several Colorado River sites (K1, K84, K140, K198, BP, and PD).

\begin{tabular}{|c|c|c|c|c|c|}
\hline No. & Site & Location & $\%$ EMBED & \% Canopy & Elevation $(\mathrm{m})$ \\
\hline \multicolumn{6}{|c|}{ Little Colorado River } \\
\hline 1 & Upper East Fork (EF) & $109^{\circ} 29^{\prime} \mathrm{W}, 33^{\circ} 56^{\prime} \mathrm{N}$ & 10 & 10 & 2797 \\
\hline 2 & Sheeps Crossing West Fork (SC) & $109^{\circ} 27^{\prime} \mathrm{W}, 33^{\circ} 58^{\prime} \mathrm{N}$ & 5 & 90 & 2757 \\
\hline 3 & Greer East Fork (GE) & $109^{\circ} 27^{\prime} \mathrm{W}, 33^{\circ} 60^{\prime} \mathrm{N}$ & 5 & 90 & 2600 \\
\hline 4 & Greer West Fork (GW) & $109^{\circ} 28^{\prime} \mathrm{W}, 33^{\circ} 60^{\prime} \mathrm{N}$ & 5 & 90 & 2541 \\
\hline 5 & Greer (GR) & $109^{\circ} 27^{\prime} \mathrm{W}, 34^{\circ} 00^{\prime} \mathrm{N}$ & 10 & 75 & 2539 \\
\hline 6 & South Fork (SF) & $109^{\circ} 25^{\prime} \mathrm{W}, 34^{\circ} 05^{\prime} \mathrm{N}$ & 30 & 70 & 2290 \\
\hline 7 & Eagar LCR (EA) & $109^{\circ} 19^{\prime} \mathrm{W}, 34^{\circ} 07^{\prime} \mathrm{N}$ & 85 & 10 & 2114 \\
\hline 8 & Springerville LCR $(\mathrm{SP})$ & $109^{\circ} 18^{\prime} \mathrm{W}, 34^{\circ} 09^{\prime} \mathrm{N}$ & 95 & 10 & 2042 \\
\hline 9 & Access Rd LCR (TE) & $109^{\circ} 21^{\prime} \mathrm{W}, 34^{\circ} 17^{\prime} \mathrm{N}$ & 90 & 10 & 1850 \\
\hline 10 & Holbrook (HO) & $110^{\circ} 40^{\prime} \mathrm{W}, 34^{\circ} 85^{\prime} \mathrm{N}$ & 100 & 0 & 1524 \\
\hline 11 & Winslow LCR (WI) & $110^{\circ} 42^{\prime} \mathrm{W}, 35^{\circ} 15^{\prime} \mathrm{N}$ & 100 & 0 & 1500 \\
\hline 12 & Cameron LCR (CA) & $111^{\circ} 34^{\prime} \mathrm{W}, 35^{\circ} 55^{\prime} \mathrm{N}$ & 100 & 0 & 1212 \\
\hline 13 & Grand Canyon confluence (GC) & $111^{\circ} 47^{\prime} \mathrm{W}, 36^{\circ} 14^{\prime} \mathrm{N}$ & 90 & 20 & 830 \\
\hline \multicolumn{6}{|c|}{ Verde River } \\
\hline 14 & Upper Verde River Paulden (UP) & $112^{\circ} 26^{\prime} \mathrm{W}, 39^{\circ} 52^{\prime} \mathrm{N}$ & 35 & 75 & 1275 \\
\hline 15 & Tuzigoot Bridge Verde River (TB) & $111^{\circ} 51^{\prime} \mathrm{W}, 34^{\circ} 33^{\prime} \mathrm{N}$ & 85 & 10 & 1010 \\
\hline 16 & Camp Verde (CV) & $111^{\circ} 51^{\prime} \mathrm{W}, 34^{\circ} 33^{\prime} \mathrm{N}$ & 90 & 20 & 959 \\
\hline \multicolumn{6}{|c|}{ Gila River } \\
\hline 17 & Gila River Grapevine, NM (GV) & $108^{\circ} 12^{\prime} \mathrm{W}, 33^{\circ} 11^{\prime} \mathrm{N}$ & 45 & 60 & 1707 \\
\hline 18 & Gila River Duncan (DU) & $109^{\circ} 06^{\prime} \mathrm{W}, 32^{\circ} 44^{\prime} \mathrm{N}$ & 85 & 20 & 1118 \\
\hline 19 & Gila River Yuma $(Y U)$ & $109^{\circ} 25^{\prime} \mathrm{W}, 32^{\circ} 46^{\prime} \mathrm{N}$ & 95 & 5 & 45 \\
\hline \multicolumn{6}{|c|}{ Colorado River } \\
\hline 20 & River kilometer $0(\mathrm{~K} 1)$ & $111^{\circ} 36^{\prime} \mathrm{W}, 36^{\circ} 52^{\prime} \mathrm{N}$ & 95 & 5 & 947 \\
\hline 21 & River kilometer 15 (K15) & $111^{\circ} 39^{\prime} \mathrm{W}, 36^{\circ} 46^{\prime} \mathrm{N}$ & 95 & 5 & 930 \\
\hline 22 & River kilometer 50 (K50) & $111^{\circ} 46^{\prime} \mathrm{W}, 36^{\circ} 41^{\prime} \mathrm{N}$ & 95 & 5 & 871 \\
\hline 23 & River kilometer 62 (K62) & $111^{\circ} 50^{\prime} \mathrm{W}, 36^{\circ} 29^{\prime} \mathrm{N}$ & 95 & 5 & 850 \\
\hline 24 & River kilometer 84 (K84) & $111^{\circ} 53^{\prime} \mathrm{W}, 36^{\circ} 17^{\prime} \mathrm{N}$ & 95 & 5 & 835 \\
\hline 25 & River kilometer 140 (K140) & $112^{\circ} 06^{\prime} \mathrm{W}, 36^{\circ} 06^{\prime} \mathrm{N}$ & 95 & 5 & 734 \\
\hline 26 & River kilometer 198 (K198) & $112^{\circ} 16^{\prime} \mathrm{W}, 36^{\circ} 07^{\prime} \mathrm{N}$ & 95 & 5 & 629 \\
\hline 27 & River kilometer 290 (K290) & $113^{\circ} 06^{\prime} \mathrm{W}, 36^{\circ} 12^{\prime} \mathrm{N}$ & 95 & 5 & 535 \\
\hline 28 & River kilometer 309 (K309) & $113^{\circ} 20^{\prime} \mathrm{W}, 36^{\circ} 04^{\prime} \mathrm{N}$ & 95 & 5 & 475 \\
\hline 29 & River kilometer 346 (K346) & $113^{\circ} 10^{\prime} \mathrm{W}, 35^{\circ} 53^{\prime} \mathrm{N}$ & 95 & 5 & 412 \\
\hline 30 & River kilometer 402 (K402) & $113^{\circ} 40^{\prime} \mathrm{W}, 35^{\circ} 51^{\prime} \mathrm{N}$ & 95 & 5 & 400 \\
\hline 31 & Bullhead, AZ Park (BP) & $114^{\circ} 35^{\prime} \mathrm{W}, 35^{\circ} 07^{\prime} \mathrm{N}$ & 95 & 5 & 230 \\
\hline 32 & Lake Havasu Marina (LH) & $114^{\circ} 21^{\prime} \mathrm{W}, 34^{\circ} 29^{\prime} \mathrm{N}$ & 95 & 5 & 224 \\
\hline 33 & $3.5 \mathrm{~km}$ below Parker Dam (PD) & $114^{\circ} 11^{\prime} \mathrm{W}, 34^{\circ} 15^{\prime} \mathrm{N}$ & 95 & 5 & 129 \\
\hline
\end{tabular}

between 2200 and $1000 \mathrm{~m}$ were agricultural (i.e., ranching areas), and those $<1000 \mathrm{~m}$ were desert (Fig. 1). Feeder systems of the LCR originate at about $3400 \mathrm{~m}$ in the White Mountains of eastern Arizona and join the Colorado River some $650 \mathrm{~km}$ downstream in the Colorado Plateau shrublands at an elevation of $830 \mathrm{~m}$ (Ricketts et al. 1999). The Gila River originates in the Black Range on the western slope of the Continental Divide in New Mexico at $3100 \mathrm{~m}$, crosses into Arizona at $1325 \mathrm{~m}$, and travels through the Chihuahuan and Sonoran deserts for nearly $1050 \mathrm{~km}$ to join the Colorado River at an elevation of about $40 \mathrm{~m}$. Midsections of the LCR and Gila rivers are intermittent due to irrigation and regulation by dams, respectively (Blinn and Poff 2005). The Verde River originates in the Arizona mountain forests in western Arizona at an elevation of $1325 \mathrm{~m}$ and joins the Gila River near Phoenix, Arizona, at $340 \mathrm{~m}$ on the northern edge of the Sonoran Desert. Finally, the Colorado River in Arizona begins near the Utah-Arizona border at $947 \mathrm{~m}$ and has highly regulated flows from 5 mainstem dams as it meanders for over $900 \mathrm{~km}$ through the Mohave and Sonoran deserts before emptying into the Gulf of California at $>50 \mathrm{~m}$ elevation (Blinn and Poff 2005). Collection sites along the LCR ranged from $830 \mathrm{~m}$ to $2797 \mathrm{~m}$, while sites in the other 3 rivers were all $<2200 \mathrm{~m}$ (Table 1). 


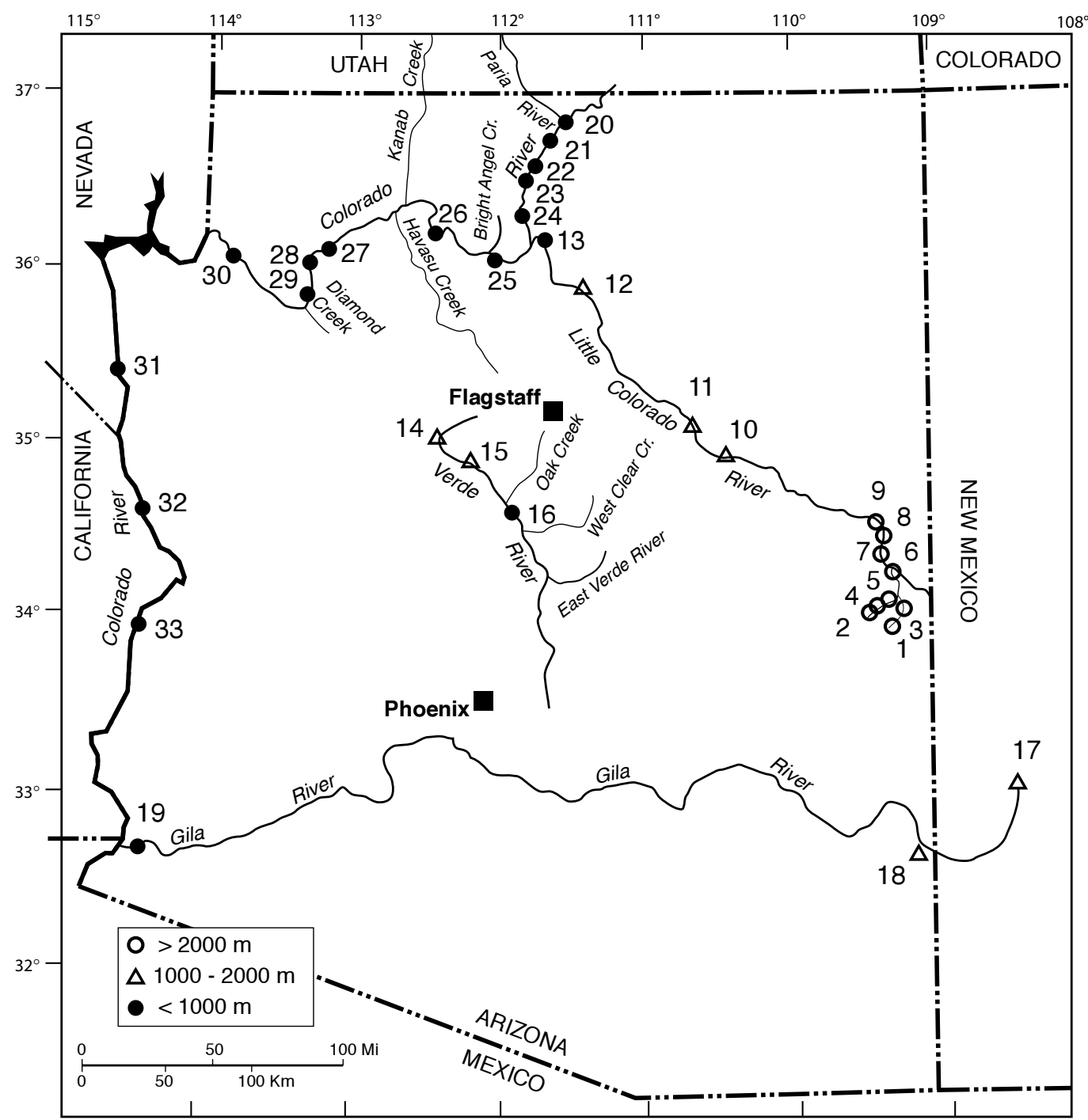

Fig. 1. Map of 33 collection sites for caddisflies at 3 elevation ranges along the Little Colorado, Verde, Gila, and Colorado rivers in Arizona during 2000-2004.

\section{METHODS}

Caddisfly larvae and pupae were handpicked from submerged vegetation, rocks, and woody debris for approximately 30 minutes during each site visit. Adult caddisflies were collected with a vertical, $30-\mathrm{cm}, 8$-watt, portable, ultraviolet light over a 19-L white plastic bucket between early May and early September in the years 2000 to 2004. Light traps were placed near the stream site 1 hour after sunset and retrieved after 3-4 hours. All collections were placed in $70 \%$ ethanol and sorted in the laboratory. Species abundance was determined as the percentage of captured adults within an elevation range and ranked as rare $(<2 \%)$, common $(2 \%-20 \%)$, or abundant $(>20 \%$; Table 2$)$. A diversity index $\left(\mathrm{H}^{\prime}\right)$ was calculated for caddisfly assemblages at each site (Shannon and Weaver 1949). A Sørensen similarity index (SI; Sørensen 1948) was used to compare paired caddisfly assemblages among the 4 river systems. Specimens are in the collections of D.E. Ruiter. 


\section{RESULTS}

Seventy-two caddisfly species in 36 genera and 15 families were represented in the 3010 specimens collected in the 4 river systems (Table 2). Fifty-five species were collected in the LCR, 17 in the Verde River, 15 in the Colorado River, and 13 in the Gila River.

Distinct assemblages were found at each elevation range. Caddisfly assemblages above $2200 \mathrm{~m}$ included 48 species in 31 genera and 15 families (Table 2). These sites were located only in the upper LCR (Fig. 1, Table 2). Brachycentrids, hydropsychids, limnephilids, and uenoids made up nearly $50 \%$ of the caddisfly assemblage. Limnephilids were most diverse but never abundant at any site. Dominant species included Brachycentrus americanus, B. occidentalis, Ceratopsyche oslari, C. venada, Gumaga griseola, Hydroptila arctia, Ithytrichia mexicana, Lepidostoma unicolor, Oligophlebodes minutus, Polycentropus arizonensis, and $P$. gertschi.

Twenty-eight species in 17 genera and 8 families were collected at sites between 2200 and $1000 \mathrm{~m}$ (Table 2). These sites were located on the lower Little Colorado and upper Gila and Verde rivers (Fig. 1, Table 2). Hydropsychids, hydroptilids, and leptocerids made up
$75 \%$ of the caddisfly assemblage at this elevation range. Dominant species included Cheumatopsyche enonis, Hydropsyche auricolor, Hydropsyche occidentalis, Hydroptila arctia, Smicridea dispar, and S. signata.

Sites within desert watersheds below $1000 \mathrm{~m}$ included 25 species in 16 genera and 7 families. These sites were located on the lower Gila and Verde rivers and the Colorado River (Fig. 2, Table 2). Hydropsychids, hydroptilids, and leptocerids made up $80 \%$ of the caddisfly assemblage with Hydroptila ajax, H. arctia, Ochrotrichia logana, Oxyethira arizona, and Smicridea fasciatella being the dominant species.

Species richness averaged $16\left(s_{\bar{x}}=1.5, n=\right.$ $6)$ at sites above $2200 \mathrm{~m}, 7\left(s_{\bar{x}}=1.4, n=10\right)$ between 2200 and $1000 \mathrm{~m}$, and $3\left(s_{\bar{x}}=0.6, n=\right.$ 17) below $1000 \mathrm{~m}$. H' diversity also declined with decreasing elevation. Values were $>3.0$ at sites above $2200 \mathrm{~m}$, from 2.5 to 0.2 between 2200 and $1000 \mathrm{~m}$, and from 1.0 to 0.5 below $1000 \mathrm{~m}$.

Caddisfly assemblages were different in each of the 4 river systems. Sørensen similarity index (SI) values ranged from 0.28 to 0.03 for paired-river comparisons. Less than $35 \%$ of the species in the Colorado, Gila, and Verde rivers were found in the LCR system, and $<33 \%$ of the species were common in the Verde

TABLE 2. Location (LOCA), emergence period (EMER), and abundance (ABUN) of caddisfly species along elevational ranges in the Little Colorado, Verde, Gila, and Colorado rivers, Arizona, during 2000-2004. Species without emergence data were collected as larvae or pupae. $\mathrm{R}=$ rare $(<2 \%)$; $\mathrm{C}=$ common $(2-20 \%)$; $\mathrm{A}=$ abundant $(>20 \%)$. GPS locations and acronyms are provided in Table 1 . Grapevine (GV) collections were made by O.S. Flint. Sites along the Verde, Gila and Colorado rivers were typically visited once, while sites on the Little Colorado River were visited multiple times.

\begin{tabular}{|c|c|c|c|c|c|c|}
\hline \multirow[b]{2}{*}{ Species } & \multicolumn{3}{|c|}{$\begin{array}{l}\text { Little Colorado } \\
\text { River }\end{array}$} & \multirow{2}{*}{$\begin{array}{l}\text { Verde } \\
\text { River }\end{array}$} & \multirow{2}{*}{$\begin{array}{l}\text { Gila } \\
\text { River }\end{array}$} & \multirow{2}{*}{$\begin{array}{l}\text { Colorado } \\
\text { River }\end{array}$} \\
\hline & LOCA & EMER & ABUN & & & \\
\hline$>2200 \mathrm{~m}$ elevation & & & & & No Data & \\
\hline $\begin{array}{l}\text { APATANIIDAE } \\
\text { Apatania arizona }\end{array}$ & SC, GW & & & & & \\
\hline $\begin{array}{l}\text { BRACHYCENTRIDAE } \\
\text { Brachycentrus americanus } \\
\text { B. occidentalis } \\
\text { Micrasema } \mathrm{sp} .\end{array}$ & $\begin{array}{l}\text { GE, SC, GW, GR } \\
\text { EF, SC, GW, GR } \\
\text { GE, SF }\end{array}$ & $\begin{array}{l}2 \mathrm{Jul}-30 \text { Aug } \\
25 \mathrm{Jul}-30 \text { Aug }\end{array}$ & $\begin{array}{l}\mathrm{C} \\
\mathrm{C} \\
\mathrm{R}\end{array}$ & & & \\
\hline $\begin{array}{l}\text { GLOSSOSOMATIDAE } \\
\text { Agapetus boulderensis } \\
\text { Culoptila moselyi } \\
\text { Glossosoma ventrale }\end{array}$ & $\begin{array}{l}\text { GW, GR, SF } \\
\text { GE, GR SF } \\
\text { GW }\end{array}$ & $\begin{array}{l}23 \text { Jul } \\
5 \text { May-22 Jun }\end{array}$ & $\begin{array}{l}\mathrm{R} \\
\mathrm{R} \\
\mathrm{R}\end{array}$ & & & \\
\hline $\begin{array}{l}\text { HELICOPSYCHIDAE } \\
\text { Helicopsyche borealis } \\
\text { H. mexicana }\end{array}$ & $\begin{array}{l}\text { GE, GR, SF } \\
\text { SF }\end{array}$ & 21 Jun-3 Jul & $\begin{array}{l}\mathrm{R} \\
\mathrm{R}\end{array}$ & & & \\
\hline
\end{tabular}


TABLE 2. Continued.

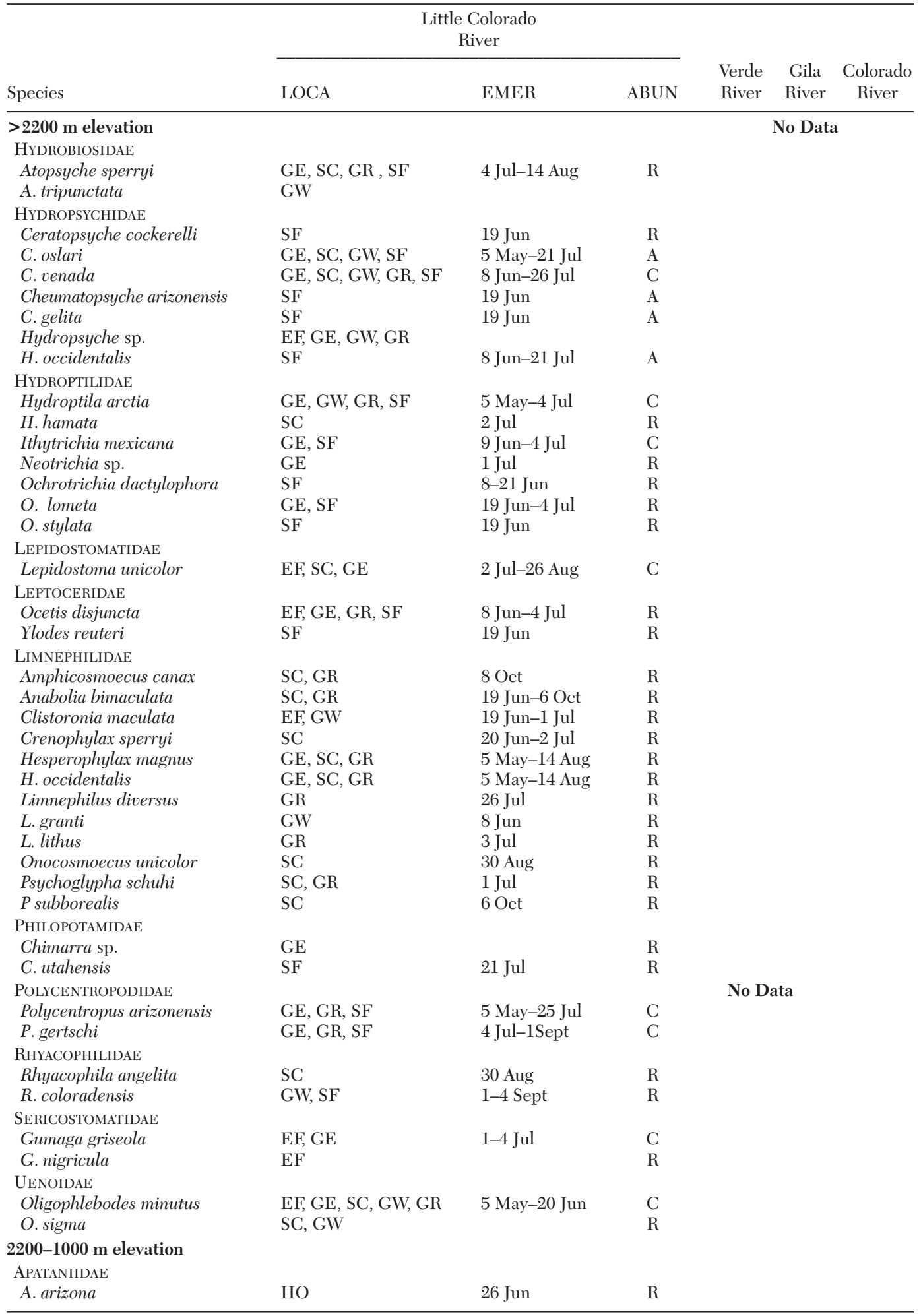




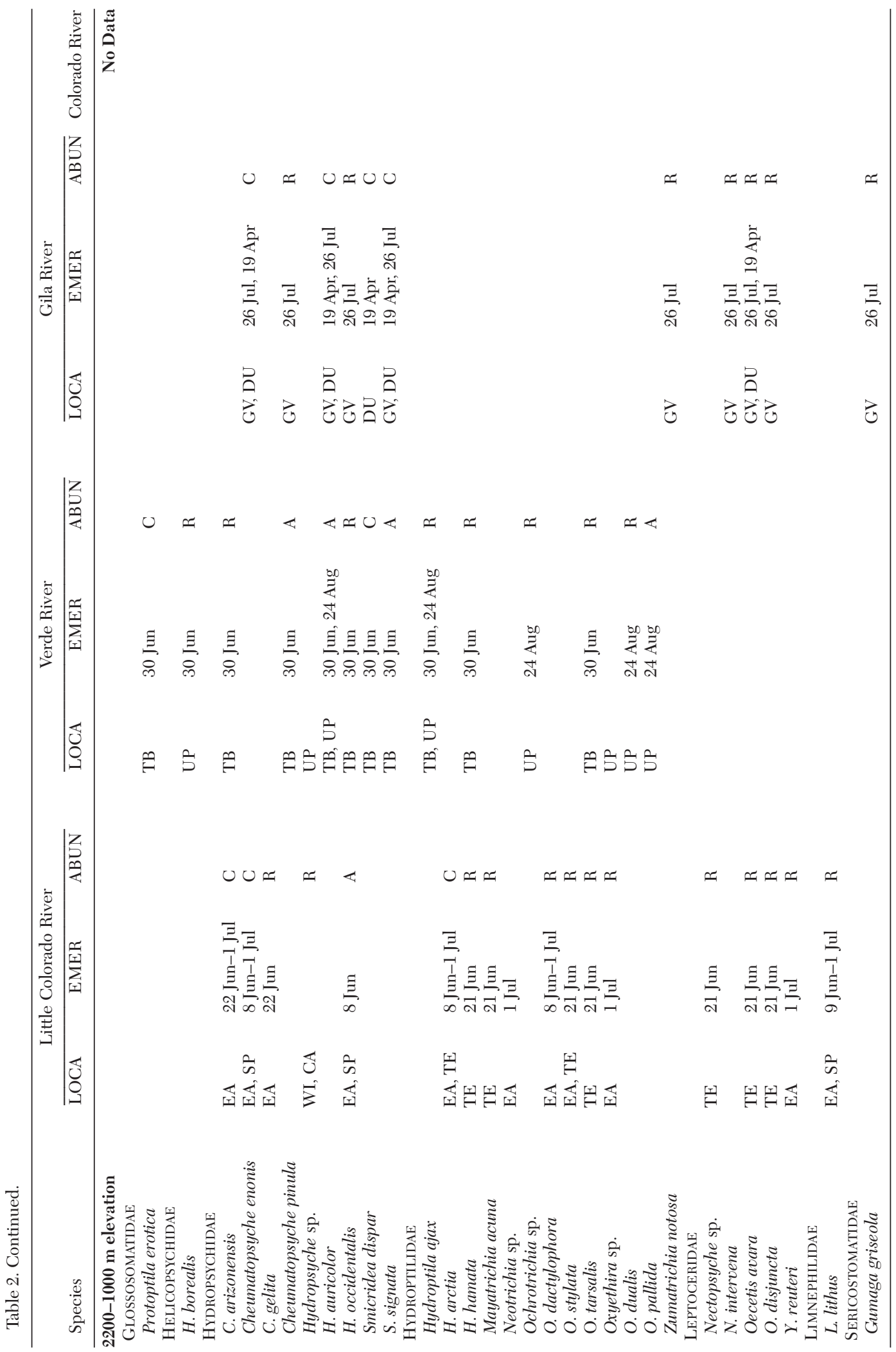




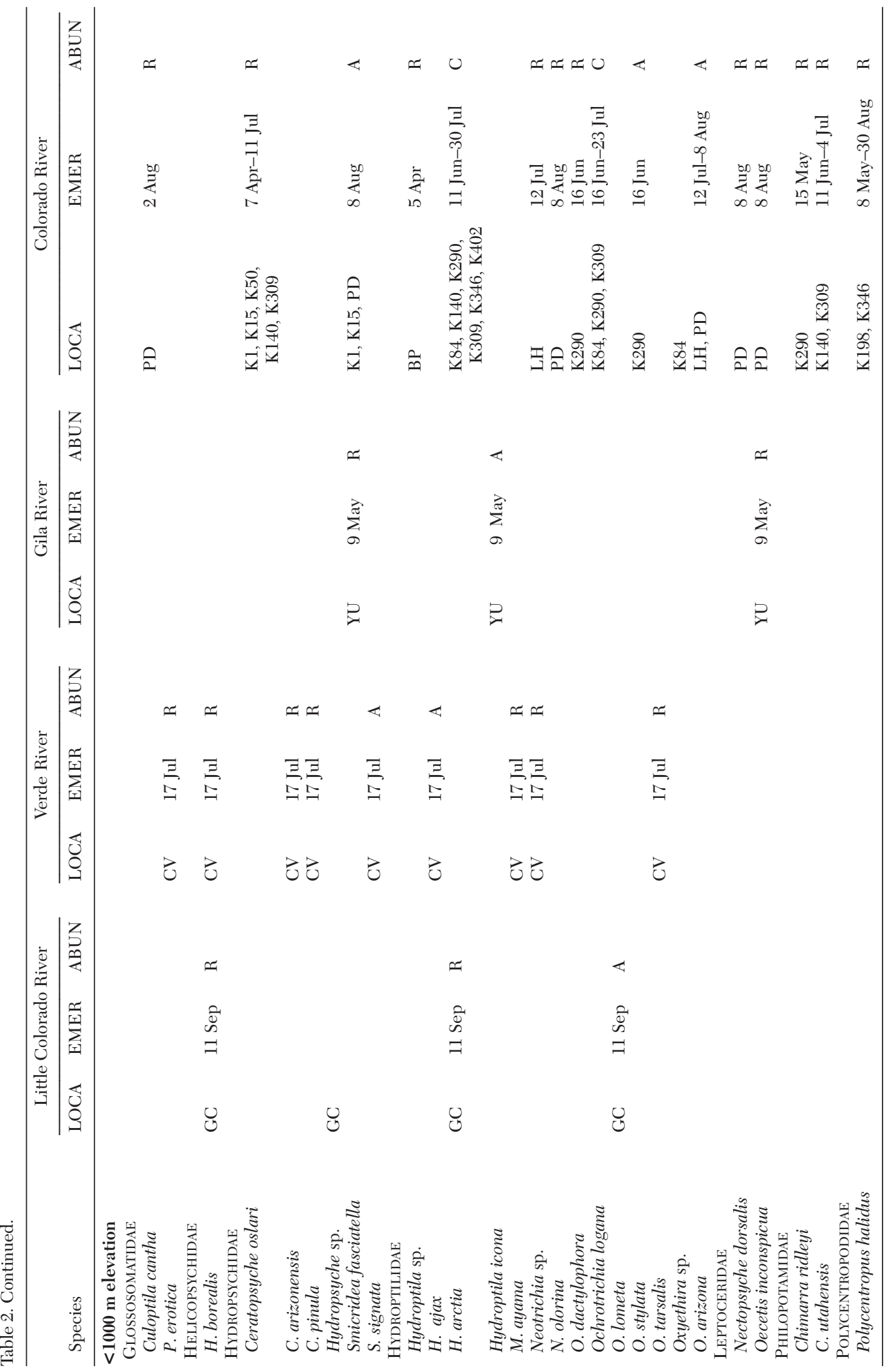


and Gila rivers at comparable elevations. SI values were especially low $(\leq 0.14)$ between the Colorado River and the other 3 rivers.

\section{Discussion}

Caddisfly assemblages in channels changed dramatically along elevation gradients and land-use variations in the Colorado, Gila, Little Colorado, and Verde rivers in Arizona. Seventy-two species were collected along these changing watersheds, including over half of the species currently reported from the state. Nine additional species have been reported in these 4 drainages. These include Hydroptila rono and Ochrotrichia ildria in the south fork and Lepidostoma ormeum in the west fork of the LCR reported by Houghton (2001), Limnephilus abbreviatus and Limnephilus spinatus in the LCR drainage reported by Ruiter (1996), and Hydroptila icona, Oecetis avara, Polycentropus arizonensis, and Smicridea arizonensis in the Verde River reported by Moulton et al. (1994).

Caddisfly assemblages at elevations $>2200$ $\mathrm{m}$ were most diverse with $70 \%$ of the species collected at these sites. There was also a decrease in $\mathrm{H}^{\prime}$ diversity from $>3$ at sites $>2200$ $\mathrm{m}$ to 0.5 at elevations $<1000 \mathrm{~m}$. Wilhm (1970) suggested macroinvertebrate assemblages with $\mathrm{H}^{\prime}>3$ were associated with unpolluted waters while those with $\mathrm{H}^{\prime}<0.5$ were in polluted or disturbed waters.

Species of Agapetus, Amphicosmoecus, Anabolia, Atopsyche, Clistorina, Crenophylax, Hesperophylax, Lepidostoma, Micrasema, Oligophlebodes, Onocosmoecus, Psychoglypha, and Rhyacophila were not collected below $2200 \mathrm{~m}$, and Mayatrichia, Nectopsyche, Oxyethira, Protoptila, Smicridea, and Zumatrichia were not collected above $2200 \mathrm{~m}$. However, Blinn and Ruiter (2009) recently reported Hesperophylax magnus, Lepidostoma aporna and Lepidostoma knulli below $2200 \mathrm{~m}$ in upper Oak Creek, Arizona.

Changes from mesic to semiarid conditions along elevation gradients likely played a role in the dramatic decrease in species richness, but intense agriculture, ranching, and river regulation were mainly responsible for these declines (Blinn and Poff 2005). Blinn and Ruiter (2006) reported that channel embeddedness averaged $10 \%\left(s_{\bar{x}}=4.6, n=22\right)$ at $>2200 \mathrm{~m}, 37.8 \%\left(s_{\bar{x}}=4.1, n=49\right)$ at elevations between 2200 and $1000 \mathrm{~m}$, and $82.7 \%\left(s_{\bar{x}}=\right.$ $4.5, n=22)$ at elevations $<1000 \mathrm{~m}$. The limited sample frequency at lower-elevation sites, in part due to ephemeral conditions, likely reduced the overall number of species collected. Additional sampling is recommended for this region.

Channels below $1000 \mathrm{~m}$ were highly regulated, especially those in the Colorado and Gila rivers (Blinn and Poff 2005). Species richness at these sites was 5-times lower than it was at sites in unregulated channels $>2200 \mathrm{~m}$. Water diversions along the lower LCR at elevations between 2200 and 1000 m likely caused similar reductions in species richness. Only 1 caddisfly species was collected at each site with intermittent flows along the lower LCR. However, sites in the lowest $21 \mathrm{~km}$ of the LCR, near the Grand Canyon confluence, are fed by waters from Blue Springs (Blinn and Poff 2005). These waters have high specific conductance $(>3 \mathrm{mS})$ but still provide habitat for Helicopsyche borealis, Hydropsyche sp., $H$. arctia, and Ochrotrichia lometa.

Table 3 provides a list of indicator caddisfly species in altered (highly disturbed) and less disturbed stream channels at high and low elevations in Arizona. The list is based on information from Blinn and Ruiter (2006) and from this study and includes a combined total of 104 stream sites throughout Arizona. High channel embeddedness was used as the criterion for disturbed sites; it is caused by altered landscapes and reduced canopy and oftentimes occurs concomitantly with high nutrients (Laws 2000). Species in less disturbed channels at high and mid-elevations were distinctly different with only Atopsyche sperryi and $H$. magnus common in the 2 upper-elevation ranges. No species were provided in the less disturbed category $<1000 \mathrm{~m}$ due to excessive agriculture, channelization, invasion of exotic riparian vegetation, water diversion, and regulation (Blinn and Poff 2005).

Hydroptila arctia was the only species common in highly disturbed sites at all 3 elevation ranges (Table 3), while Cheumatopsyche arizonensis and Cheumatopsyche pinula were in the 2 upper ranges. This observation suggests that these species have a wide tolerance for environmental disturbance. The caddisfly assemblage in the highly disturbed channels at sites $<1000$ $\mathrm{m}$ is mainly associated with the highly regulated Colorado River since only 2 other sites (Camp 
TABLE 3. Caddisfly assemblages in Arizona rivers in less disturbed and highly disturbed channels at high $(>2200 \mathrm{~m})$, mid $(1000-2200 \mathrm{~m})$, and low $(<1000 \mathrm{~m})$ elevations. Channel embeddedness is $<10 \%$ in less disturbed river channels and $>30 \%$ in highly disturbed channels

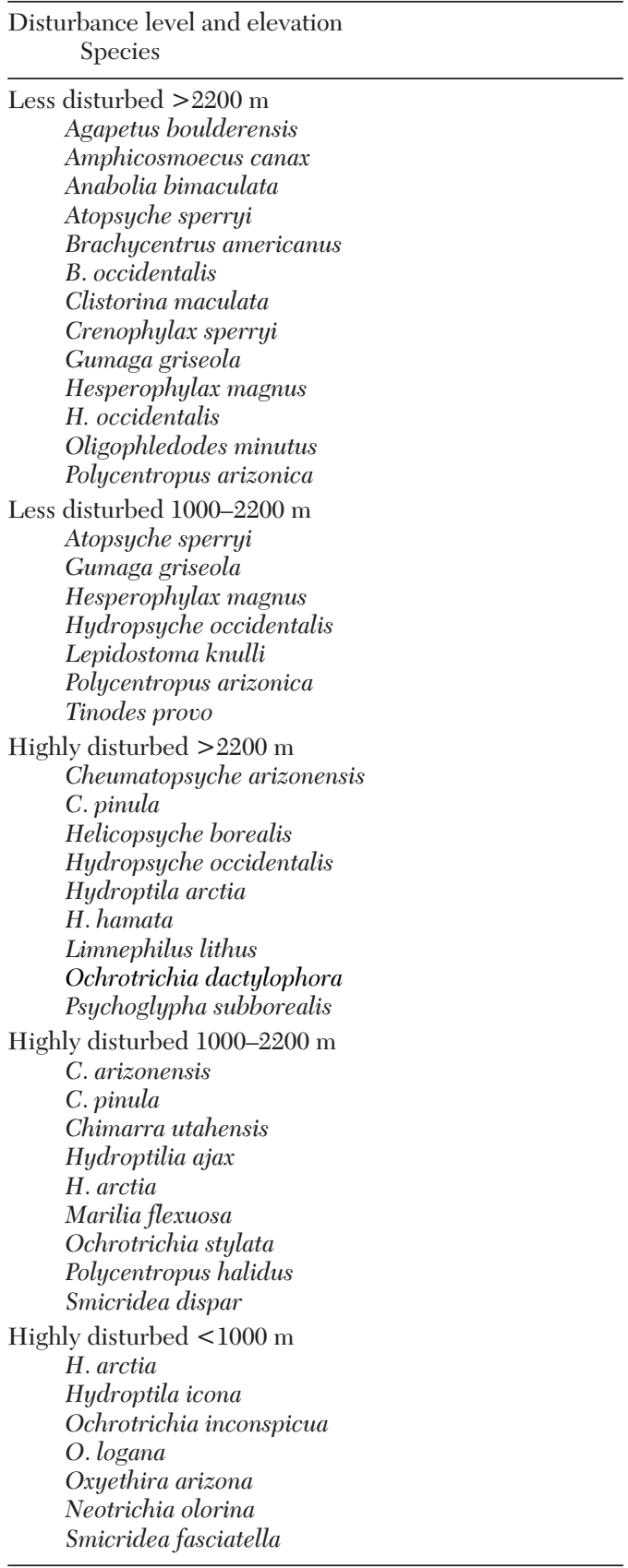

Verde River and the Gila River near Yuma) were sampled at elevations $<1000 \mathrm{~m}$. Ceratopysche oslari also occurred throughout the regulated Colorado River but at a low abundance.
A nonmetric multidimensional ordination of Arizona caddisflies by Blinn and Ruiter (2005) also showed species listed in the less disturbed category of Table 3 to be closely associated with dense riparian canopies, low water temperature, low specific conductance, and low channel embeddedness, while those in the highly disturbed category were closely associated with reduced canopies, high water temperature, high specific conductance, and high channel embeddedness. Generally, Barbour et al. (1999) reported similar regional tolerances for species listed in each category.

The indicator assemblages in Table 3 may be applicable in adjacent western semiarid regions. Ward et al. (2002) found similar species assemblages in major river basins in Colorado. Barbour et al. (1999) also reported similar tolerances to water quality for these species in other regions of the United States.

Recent collections in Arizona have yielded 7 additional species records for the state. These include Neotrichia okopa in the Salt River, Phylloicus mexicanus in the south fork of Cave Creek (Chiricahua Mountains), Helicopsyche probolata in the north fork of the White River, and Hesperophylax consimilis in Upper West Fork in the White Mountains-all part of the Gila River drainage. In addition, Neotrichia olorina was collected below Parker Dam in the Colorado River. Also, Ruiter (2007) described Neotrichia blinni and N. sandyae from the LCR and Gila River watersheds, respectively. These reports combined update the lists in Blinn and Ruiter $(2005,2006,2009)$ to a total of 154 caddisfly species reported from Arizona.

We provide a baseline of indicator caddisfly species for monitoring changes in ecosystem health along major drainages in Arizona during the predicted long-term drought and population expansion in southwestern USA (Seager et al. 2007). Some areas were not sampled due to difficult access, including the "sky islands" in the southeastern part of the state. Aquatic habitats associated with these isolated sky islands are somewhat protected from anthropogenic activities and are clearly distinct from the surrounding desert and semidesert grasslands (Ricketts et al. 1999). Therefore, investigations on these habitats as well as on those in ephemeral streams may provide further insight into caddisfly assemblages in southwestern USA. 


\section{ACKNOWLEDGMENTS}

We thank Robert Delph, William Liebfreid, Charles Minckley, Joseph Shannon, and Michael Yard for their assistance with field collections. I (DWB) especially thank my wife Sandra for her assistance and companionship during this study. We also thank O.S. Flint for providing data on the Gila River at the Grapevine Campground in New Mexico and 2 anonymous reviewers and Mark Belk for improving an earlier version of the manuscript.

\section{Literature Cited}

Barbour, M.T., J. Gerritson, B.D. Snyder, and J.B. STRIBING. 1999. Rapid bioassessment protocols for use in wadeable streams and rivers: periphyton, benthic macroinvertebrates, and fish. 2nd edition. EPA 841-B-99-002, U.S. Environmental Protection Agency, Office of Water, Washington, DC.

Blinn, D.W., AND N.L. Poff. 2005. Colorado River Basin. Pages 483-538 in A.C. Benke and C.E. Cushing, editors, Rivers of North America. Academic Press, San Diego, CA.

Blinn, D.W., and D.E. Ruiter. 2005. Caddisfly (Trichoptera) community structure and distribution in Arizona, USA: effects of selected environmental determinants. Pages 63-71 in K. Tanida and A. Rossiter, editors, Proceedings of the 11th International Symposium on Trichoptera (2003. Osaka). Tokai University Press, Osaka, Japan.

2006. Tolerance values of stream caddisflies (Trichoptera) in the Lower Colorado River Basin, USA. Southwestern Naturalist 51:326-337.

. 2009. Phenology and distribution of caddisflies (Trichoptera) in Oak Creek, a desert perennial stream in Arizona. Southwestern Naturalist 54:182-194.

Dehoney, B., AND W. Gaud. 1983. Seasonal analysis of aquatic invertebrates and detritus in a small mountain stream in Arizona. Southwestern Naturalist 28: 189-198.

Houghton, D.C. 2001. Caddisfly (Trichoptera) records from the Apache National Forest, Eastern Arizona. Entomological News 112:85-93.

LawS, E.A. 2000. Aquatic pollution: an introductory text. 3rd edition. John Wiley \& Sons, Inc., New York.

MAY, E. 1972. An examination of the aquatic insect populations of Oak Creek, Arizona. Master's thesis, Northern Arizona University, Flagstaff.
Moulton, S.R., II, K.W. Stewart, and K.L. Young. 1994. New records, distribution and taxonomic status of some northern Arizona caddisflies (Trichoptera). Entomological News 105:164-174.

PARRotT, J.F. 1975. Seasonal analysis of aquatic insect populations in Oak Creek, Arizona. Master's thesis, Northern Arizona University, Flagstaff.

Ricketts, T.H., E. Dinerstein, D.M. Olson, C.J. Loucks, ET AL. 1999. Terrestrial ecoregions of North America: a conservation assessment. Island Press, Washington, DC.

Ruiter, D.E. 1996. Initial list of Trichoptera collected in the USA by 1995 symposium participants. Braueria 23:10-12.

2007. Two new species of Neotrichia from Arizona, U.S.A. (Trichoptera: Hydroptilidae). Pages 275-277 in J. Bueno-Soría, R. Barba-Álvarez, and B.J. Armitage, editors, Proceedings of the XIIth International Symposium on Trichoptera. Caddis Press, Columbia, OH.

ScotT, J. 1982. Seasonal abundance and distribution of benthic insects at Pumphouse Wash and Chavez Crossing in Oak Creek, Arizona. Master's thesis, Northern Arizona University, Flagstaff.

Seager, R., M. Ting, I. Held, Y. Kushnir, J. Lu, G. VecChi, H.-P. Huang, N. Harnik, A. Leetmaa, N.-C. LAU, C. Li, J. VELEZ, AND N. NAIK. 2007. Model projections of an imminent transition to a more arid climate in southwestern North America. Science 316: $1181-1184$.

Shannon, C.E., AND W. Weaver. 1949. The mathematical theory of communication. University of Illinois Press, Urbana.

SøRENSEN, T.A. 1948. A method of establishing groups of equal amplitude in plant sociology based on similarity of species content. Kongelige Danske Videnskabernes Selskab 5:1-34.

SPINDLER, P. 1996. Using ecoregions for explaining macroinvertebrate community distribution among reference sites in Arizona, 1992. Arizona Department of Environmental Quality, Phoenix.

Ward, J.V., B.C. KondratiefF, and R.E. Zuelling. 2002. An illustrated guide to the mountain stream insects of Colorado. 2nd edition. University Press of Colorado, Boulder.

Wilhm, J.L. 1970. Range of diversity index in benthic macroinvertebrate populations. Journal of the Water Pollution Control Federation 42:R221-I1224.

Received 3 March 2008 Accepted 27 April 2009 